Jurnal ISLAMIKA, Vol. 3, No. 2 (2020): 24-35

\title{
Dicipline Management Strategy
}

\author{
Rika Aryani \\ STAI SMQ Bangko, Indonesia \\ Email: Rikaariyani857@gmail.com \\ Sakban \\ STAI Madina Panyabungan Kabupaten Mandailing Natal \\ Email: sakbanlubis80@gmail.com
}

\begin{abstract}
In a organization, good of education organization and also other organization, human resource represent central factor and very required by $\mathrm{a}[\mathrm{n}$ organization. Without existence of human resource, organizational will not mean something. Therefore, human resource require to be managed by professional so that organization can expand productively, and employees can work better. Employees performance influenced by various factor, for example: activity environment, leadership, activity motivation, as well as activity discipline. Activity discipline represent conscious attitude or readiness a employees to do and adhere specified orders. Employees with activity discipline which is good to be expected can execute and finish work becoming its responsibility effectively and efficient and also on time. As for discipline management strategy shall be as follows 1) its clear Decision formula, its sensible order, publicized, and run neglectlessly 2) Its fair execution by using enunciated law and commemoration 3) Leadership of accomodated supervision at discipline orders 4) uniform and fair execution.
\end{abstract}

Keyword: Strategy Management, Management, Management Discipline

\begin{abstract}
Abstrak
Dalam sebuah organisasi, baik organisasi pendidikan maupun organisasi lainnya, sumber daya manusia merupakan faktor sentral dan sangat dibutuhkan oleh suatu organisasi. Tanpa adanya sumber daya manusia, organisasi tidak akan berarti. Oleh karena itu, sumber daya manusia perlu dikelola secara profesional agar organisasi dapat berkembang secara produktif, dan karyawan dapat bekerja lebih baik. Kinerja karyawan dipengaruhi oleh berbagai faktor antara lain: lingkungan aktivitas, kepemimpinan, motivasi aktivitas, serta kedisiplinan aktivitas. Disiplin aktivitas merepresentasikan sikap sadar atau kesiapan seorang karyawan untuk melakukan dan ada perintah tertentu. Karyawan dengan disiplin aktivitas yang baik diharapkan dapat melaksanakan dan menyelesaikan pekerjaan yang menjadi tanggung jawabnya secara efektif dan efisien serta tepat waktu. Adapun strategi pengelolaan kedisiplinan adalah sebagai berikut: 1) Rumusan keputusan yang jelas, tertib yang masuk akal, dipublikasikan, dan dijalankan dengan sembarangan 2) Pelaksanaannya yang adil dengan menggunakan undang-undang dan peringatan yang ditetapkan 3)
\end{abstract}


Pimpinan pengawasan yang terakomodir atas perintah disiplin 4) seragam dan adil eksekusi.

\section{PENDAHULUAN}

Sebuah falsafah mengatakan: man behind the gun. Roda organisasi sangat tergantung pada perilaku-perilaku manusia yang bekerja di dalamnya. The right man on the right place akan membawa suatu organisasi pada hasil kinerja yang maksimal dan mengurangi kesalahan-kesalahan dalam tugas atau pekerjaan. Kinerja sumber daya manusia merupakan kunci utama yang mendukung sebuah organisasi mencapai tujuan yang telah ditetapkan. Kinerja karyawan adalah penentu keberhasilan dan kelangsungan hidup organisasi. Tanpa kinerja yang baik, organisasi tidak akan mencapai tujuannya.

Kinerja karyawan dipengaruhi oleh berbagai faktor, antara lain: lingkungan kerja, kepemimpinan, motivasi kerja, dan juga disiplin kerja. Disiplin kerja merupakan sikap sadar atau kesediaan seorang karyawan untuk melakukan dan mentaati aturan-aturan yang ditetapkan. Karyawan dengan disiplin kerja yang baik diharapkan mampu melaksanakan dan menyelesaikan pekerjaan yang menjadi tanggung jawabnya dengan efektif dan efisien serta tepat pada waktunya.

Disiplin kerja tidak hanya dilihat dari absensi, tetapi juga bisa dinilai dari sikap karyawan tersebut dalam melaksanakan pekerjaan. Karyawan yang mempunyai disiplin tinggi tidak menunda-nunda pekerjaan dan selalu berusaha menyelesaikan tepat waktu meskipun tidak ada pengawasan langsung dari atasan.

\section{PEMBAHASAN}

\section{Pengertian Disiplin}

Di dalam kehidupan sehari-hari, di mana pun manusia berada, dibutuhkan peraturan-peraturan dan ketentuan-ketentuan yang akan mengatur dan membatasi setiap kegiatan dan perilakunya. Namun peraturan-peraturan tersebut tidak akan ada artinya bila tidak disertai dengan sanksi bagi para pelanggarnya.

Menurut Terry dalam Tohardi (Ahmad Tohardi, 2008:58) disiplin merupakan alat penggerak karyawan. Agar tiap pekerjaan dapat berjalan dengan lancar, maka harus diusahakan agar ada disiplin yang baik. Terry kurang setuju jika disiplin hanya dihubungkan dengan hal-hal yang kurang menyenangkan (hukuman), karena sebenarnya hukuman merupakan alat paling akhir untuk menegakkan disiplin.

Keith Davis dalam Mangkunegara (Anwar Prabu Mangkunegara, 2003:129) mengemukakan bahwa "Dicipline is management as action to enforce organization standards" (disiplin kerja dapat diartikan sebagai pelaksanaan pedoman organisasi). Disiplin yang baik mencerminkan besarnya rasa tanggung jawab seseorang terhadap tugastugas yang diberikan kepadanya.

Menurut E. Mulyasa, disiplin adalah suatu kesadaran tertib di mana orang-orang yang berhubungan dalam suatu sistem tunduk pada peraturan-peraturan yang ada dengan senang hati (E. Mulyasa, . 2002:108)

Menurut Siagian disiplin adalah suatu bentuk pelatihan yang berusaha memperbaiki dan membentuk sikap dan perilaku karyawan sehingga para karyawan tersebut secara 
sukarela bekerja secara kooperatif dengan para karyawan lain serta meningkatkan prestasi kerjanya. (Sondang P. Siagian, 2008:305)

Disiplin adalah sikap hidup dan prilaku yang mencerminkan tanggung jawab terhadap kehidupan, tanpa paksaan dari luar. Sikap dan prilaku ini dianut berdasarkan keyakinan bahwa hal itu bermanfaat bagi diri sendiri dan masyarakat. Hal ini berkait dengan kemauan dan kemampuan seseorang menyesuaikan interennya dan mengendalikan dirinya agar sesuai dengan norma, aturan, hukum, kebiasaan yang berlaku dalam lingkungan sosial budaya setempat (Abdus Salam, 2014:194)

Menurut Hasibuan dalam Barnawi, (Arifin dan Barnawi, 2012:112), disiplin kerja adalah kemampuan kerja seseorang untuk secara teratur, tekun, terus-menerus, dan bekerja sesuai dengan aturan-aturan yang berlaku dengan tidak melanggar aturan-aturan yang sudah ditetapkan. Sedangkan Rasdiyanah menyatakan bahwa disiplin yaitu kepatuhan untuk menghormati dan melaksanakan suatu system yang mengharuskan orang untuk tunduk pada keputusan, perintah atau peraturan yang berlaku. Dengan kata lain, disiplin adalah kepatuhan mentaati peraturan dan ketentuan yang telah ditetapkan. (Arifin dan Barnawi, 2012:112)

Disiplin sangat diperlukan baik individu yang bersangkutan maupun oleh organisasi. Contoh, seorang pesuruh di sebuah kantor yang terlambat datang, akibatnya ruangan kantor tersebut semuanya terkunci sehingga kegiatan kantor menjadi terganggu. Dari contoh ini dapat kita lihat bahwa ketidakdisiplinan seseorang dapat merusak aktivitas organisasi.

Disiplin menunjukkan suatu kondisi atau sikap hormat yang ada pada diri karyawan terhadap peraturan dan ketetapan perusahaan. Dengan demikian bila peraturan atau ketetapan yang ada dalam perusahaan itu diabaikan, atau sering dilanggar, maka karyawan mempunyai disiplin kerja yang buruk. Sebaliknya, bila karyawan tunduk pada ketetapan perusahaan, menggambarkan adanya kondisi disiplin yang baik. Dalam arti yang lebih sempit dan lebih banyak dipakai, disiplin berarti tindakan yang diambil dengan penyediaan untuk mengoreksi perilaku dan sikap yang salah pada sebagian karyawan.

Dalam ajaran Islam, banyak ayat al-Qur`an dan hadist, yang memerintahkan disiplin dalam arti ketaatan pada peraturan yang telah ditetapkan. Antara lain disebutkan dalam surah an-Nisâ' ayat 59:

"Hai orang-orang yang beriman, taatilah Allah dan taatilah Rasul (nya), dan ulil amri di antara kamu. Kemudian jika kamu berlainan pendapat tentang sesuatu, Maka kembalikanlah ia kepada Allah (Al Quran) dan Rasul (sunnahnya), jika kamu benar-benar beriman kepada Allah dan hari kemudian. yang demikian itu lebih utama (bagimu) dan lebih baik akibatnya" (Qs. an-Nisâ' [4]: 59).

Dari ayat di atas terungkap pesan untuk patuh dan taat kepada para pemimpin, dan jika terjadi perselisihan di antara mereka, maka urusannya harus dikembalikan kepada aturan Allah SWT dan Rasul-Nya.

Namun, tingkat kepatuhan manusia kepada pemimpinnya tidak bersifat mutlak. Jika perintah yang diberikan pemimpin bertentangan dengan aturan atau perintah Allah dan Rasul-Nya, maka perintah tersebut harus tegas ditolak dan diselesaikan dengan musyawarah. Namun jika aturan dan perintah pemimpin tidak bertentangan dengan 
Syariat Allah dan Rasul-Nya, maka Allah menyatakan ketidaksukaannya terhadap orangorang yang melewati batas.

Di samping mengandung arti taat dan patuh pada peraturan, disiplin juga mengandung arti kepatuhan kepada perintah pemimpin, perhatian dan kontrol yang kuat terhadap penggunaan waktu, tanggungjawab atas tugas yang diamanahkan, serta kesungguhan terhadap bidang keahlian yang ditekuni. Islam mengajarkan kita agar benarbenar memperhatikan dan mengaplikasikan nilai-nilai kedisplinan dalam kehidupan sehari-hari untuk membangun kualitas kehidupan masyarakat yang lebih baik.

Pesan-pesan moral yang terkandung dalam ajaran Islam, memberi interpretasi yang lebih luas dan jelas kepada umatnya untuk berlaku dan bertindak disiplin. Bahkan dari beberapa rangkaian ibadah, seperti shalat, puasa, zakat maupun haji, terkandung perintah untuk berlaku disiplin. Dengan demikian, nilai-nilai moral ajaran Islam diharapkan mampu menjadi energi pendorong pelaksanaan kedisplinan. Dalam skala lebih luas, untuk meningkatkan kualitas kehidupan masyarakat.

Disiplin kerja sangat diperlukan untuk menunjang kelancaran segala aktivitas organisasi agar tujuan organisasi dapat dicapai secara maksimal Tujuan utama disiplin adalah untuk meningkatkan efesiensi semaksimal mungkin dengan cara mencegah pemborosan waktu dan energi. Malayu S.P Hasibuan (Malayu S.P Hasibuan, 1996:212) mengemukakan bahwa disiplin yang baik mencerminkan besarnya tanggung jawab seseorang terhadap tugas-tugas yang diberikan kepadanya karena hal ini akan mendorong gairah atau semangat kerja, dan mendorong terwujudnya tujuan organisasi.

Sedangkan kedisiplinan adalah kesadaran dan kesediaan seseorang menaati semua peraturan organisasi dan norma-norma sosial yang berlaku. Kesadaran adalah sikap seseorang yang secara sukarela menaati semua peraturan dan sadar akan tugas dan tanggung jawabnya. Jadi, seseorang akan bersedia mematuhi semua peraturan serta melaksanakan tugas-tugasnya, baik secara sukarela maupun karena terpaksa. Kesediaan adalah suatu sikap, tingkah laku, dan perbuatan seseorang yang sesuai dengan peraturan organisasi, baik yang tertulis maupun tidak. (Tulus Tu'u, 2004:63)

Ketidakdisiplinan dan kedisiplinan dapat menjadi panutan orang lain. Jika lingkungan kerja semuanya disiplin, maka seorang pegawai akan ikut disiplin, tetapi jika lingkungan kerja organisasi tidak disiplin, maka seorang pegawai juga akan ikut tidak disiplin. Untuk itu sangat sulit bagi lingkungan kerja yang tidak disiplin tetapi ingin menerapkan kedisiplinan pegawai, karena lingkungan kerja akan menjadi panutan bagi para pegawai.

Bentuk disiplin yang baik sebagaimana dikemukakan oleh Edy sutrisno, (Edy Sutrisno, 2016:86) akan tercermin pada suasana sebagai berikut:

1. Tingginya rasa kepedulian karyawan terhadap pencapaian tujuan perusahaan.

2. Tingginya semangat dan gairah kerja dan inisiatif para karyawan dalam melakukan pekerjaan.

3. Besarnya rasa tanggung jawab para karyawan untuk melaksanakan tugas dengan sebaik-baiknya.

4. Berkembangnya rasa memiliki dan rasa solidaritas yang tinggi di kalangan karyawan.

5. Meningkatnya efisiensi dan produktivitas kerja para karyawan. 
Sedangkan pembinaan disiplin bertujuan agar: 1) Tenaga kerja diharapkan menepati segala peraturan dan kebijakan ketenagakerjaan maupun peraturan dan kebijakan perusahaan yang berlaku, baik tertulis maupun tidak tertulis, serta melaksanakan perintah manajemen, 2) Dapat melaksanakan pekerjaan dengan sebaikbaiknya serta mampu memberikan pelayanan yang maksimal kepada pihak tertentu yang berkepentingan dengan perusahaan sesuai dengan bidang pekerjaan yang diberikan kepadanya, 3) Dapat menggunakan prasarana, barang dan jasa perusahaan dengan sebaikbaiknya, 4) Dapat bertindak dan berperilaku sesuai dengan norma-norma yang berlaku pada perusahaan, 5) Tenaga kerja mampu menghasilkan produktivitas yang tinggi sesuai dengan harapan perusahaan, baik dalam jangka pendek maupun jangka panjang.

Dari beberapa penjelasan di atas dapat ditarik kesimpulan bahwa disiplin adalah sikap mentaati peraturan dan ketentuan yang telah ditetapkan oleh organisasi baik yang tertulis maupun yang tidak tertulis dengan penuh kesadaran dan tidak mengelak dangan sanksi-sanksi apabila melanggar tugas dan wewenang yang diberikan kepadanya. Dengan kata lain, disiplin adalah sikap menaati peraturan dan ketentuan yang telah ditetapkan tanpa pamrih.

Disiplin kerja mempunyai beberapa indikator sebagai berikut: 1) Disiplin kerja tidak semata-mata patuh dan taat terhadap penggunaan jam kerja saja, misalnya datang dan pulang sesuai dengan jadwal, tidak mangkir jika bekerja, dan tidak mencuri-curi waktu, 2) Upaya dalam mentaati peraturan tidak didasarkan adanya perasaan takut atau terpaksa, 3) Komitmen dan loyal pada organisasi yaitu tercermin dari bagaimana sikap dalam bekerja. Apakah karyawan serius atau tidak.

\section{Prinsip-Prinsip Pendisiplinan}

Prinsip-prinsip pendisiplinan yang dikemukakan Ranupandojo dalam Asmiarsih Asmiarsih, 2006:30) adalah :

a. Dilakukan secara pribadi

Pendisiplinan seharusnya dilakukan dengan memberikan teguran kepada karyawan. Teguran jangan dilakukan di hadapan orang banyak karena dapat menyebabkan karyawan yang ditegur merasa malu dan tidak menutup kemungkinan menimbulkan rasa dendam yang dapat merugikan organisasi.

b. Pendisiplinan harus bersifat membangun.

Selain memberikan teguran dan menunjukkan kesalahan yang dilakukan karyawan, harus disertai dengan saran tentang bagaimana seharusnya berbuat untuk tidak mengulangi lagi kesalahan yang sama.

c. Pendisiplinan harus dilakukan secara langsung dengan segera.

Suatu tindakan dilakukan dengan segera setelah terbukti bahwa karyawan telah melakukan kesalahan. Jangan membiarkan masalah menjadi kadaluarsa sehingga terlupakan oleh karyawan yang bersangkutan

d. Keadilan dalam pendisiplinan sangat diperlukan.

Dalam tindakan pendisiplinan dilakukan secara adil tanpa pilih kasih. Siapapun yang telah melakukan kesalahan harus mendapat tindakan pendisiplinan secara adil tanpa membeda-bedakan.

e. Setelah pendisiplinan sikap dari pimpinan haruslah wajar kembali. 
Sikap wajar hendaknya dilakukan pimpinan terhadap karyawan yang telah melakukan kesalahan tersebut. Dengan demikian, proses kerja dapat lancar kembali dan tidak kaku dalam bersikap.

\section{Faktor-Faktor Yang Mempengaruhi Kedisiplinan}

Disiplin kerja tentu saja tidak terjadi dengan sendirinya, karena perilaku manusia itu sendiri di bentuk karena adanya faktor-faktor yang mendasarinya. Sama halnya dengan disiplin kerja yang juga memiliki beberapa faktor yang berpengaruh terhadap pembentukan perilaku disiplin dimana disiplin kerja merupakan salah satu bentuk dari perilaku manusia.

Asumsinya bahwa pemimpin mempunyai pengaruh langsung atas sikap kebiasaan yang diperoleh karyawan. Kebiasaan itu ditentukan oleh pemimpin, baik dengan iklim atau suasana kepemimpinan maupun melalui contoh diri pribadi. Karena itu, untuk mendapat disiplin yang baik, maka pemimpin harus memberikan kepemimpinan yang baik pula.

Menurut Singodimedjo, (Markum Singodimedjo, 2000:98) faktor yang mempengaruhi disiplin kerja pegawai adalah:

a. Besar kecilnya pemberian kompensasi

Besar kecilnya kompensasi dapat memengaruhi tegaknya disiplin. Para karyawan akan mematuhi segala peraturan yang berlaku, bila ia merasa mendapat jaminan balas jasa yang setimpal dengan jerih payahnya yang telah dikontribusikan bagi perusahaan. Bila ia menerima kompensasi yang memadai, mereka akan dapat bekerja tenang dan tekun, serta selalu berusaha bekerja dengan sebaik-baiknya. Akan tetapi, bila ia merasa kompensasi yang diterimanya jauh dari memadai, maka ia akan berpikir mendua, dan berusaha mencari tambahan penghasilan lain di luar, sehingga menyebabkan ia sering mangkir, sering minta izin keluar.

Namun demikian, pemberian kompensasi yang memadai belum tentu pula menjamin tegaknya disiplin. Karena pemberian kompensasi hanyalah merupakan salah satu cara meredam kegelisahan para karyawan, di samping banyak lagi hal-hal yang di luar kompensasi yang harus mendukung tegaknya disiplin kerja dalam organisasi. Realitanya dalam praktik lapangan, memang dengan dengan pemberian kompensasi yang mencukupi, sedikit banyak akan membantu karyawan untuk bekerja tenang, karena dengan menerima kompensasi yang wajar kebutuhan primer mereka akan dapat terpenuhi.

b. Ada atau tidaknya keteladanan pimpinan dalam organisasi

Keteladanan pimpinan sangat penting sekali, karena dalam lingkungan perusahaan, semua karyawan akan selalu memperhatikan bagaimana pimpinan dapat menegakkan disiplin dirinya dan bagaimana ia dapat mengendalikan dirinya dari ucapan, perbuatan, dan sikap yang dapat merugikan aturan disiplin yang sudah ditetapkan. Misalnya, bila aturan jam kerja pukul 08.00, maka si pemimpin tidak akan masuk kerja terlambat dari waktu yang sudah ditetapkan.

Peranan keteladanan pimpinan sangat berpengaruh besar dalam sebuah organisasi, bahkan sangat dominan dibandingkan dengan semua factor yang mempengaruhi disiplin dalam organisasi, karena pimpinan dalam suatu organisasi masih menjadi panutan para karyawan. Para bawahan akan selalu meniru yang dilihatnya setiap hari. Apa pun yang 
dibuat pimpinannya. Oleh sebab itu, bila seorang pemimpin menginginkan tegaknya disiplin dalam organisasi, maka ia harus lebih dulu mempraktikkan, supaya dapat diikuti dengan baik oleh para karyawan lainnya.

c. Ada tidaknya aturan pasti yang dapat dijadikan pegangan

Pembinaan disiplin tidak akan dapat terlaksana dalam perusahaan, bila tidak ada aturan tertulis yang pasti untuk dapat dijadikan pegangan bersama. Disiplin tidak mungkin ditegakkan bila peraturan yang dibuat hanya berdasarkan instruksi lisan yang dapat berubah-ubah sesuai dengan kondisi dan situasi.

Para karyawan akan mau melakukan disiplin bila ada aturan yang jelas dan diinformasikan kepada mereka. Bila aturan disiplin hanya menurut selera pimpinan saja, atau berlaku untuk orang tertentu saja, jangan diharap bahwa para karyawan akan mematuhi aturan tersebut. Oleh sebab itu, disiplin akan dapat ditegakkan dalam suatu perusahaan, jika ada aturan tertulis yang telah disepakati bersama. Dengan demikian, para karyawan akan mendapat suatu kepastian bahwa siapa saja dan perlu dikenakan sanksi tanpa pandang bulu.

d. Keberanian pimpinan dalam mengambil tindakan.

Bila ada seorang karyawan yang melanggar disiplin, maka perlu ada keberanian pimpinan untuk mengambil tindakan yang sesuai dengan tingkat pelanggaran yang dibuatnya. Dengan adanya tindakan terhadap pelanggar disiplin, sesuai dengan sanksi yang ada, maka semua karyawan akan merasa terlindungi, dan dalam hatinya berjanji tidak akan berbuat hal yang serupa. Dalam situasi demikian, maka semua karyawan akan benar-benar terhindar dari sikap sembrono, asal jadi seenaknya sendiri dalam organisasi. Sebaliknya, bila pimpinan tidak berani mengambil tindakan, walaupun sudah terang-terangan karyawan tersebut melanggar disiplin, tetapi tidak ditegur/dihukum, maka akan berpengaruh kepada suasana kerja dalam organisasi. Para karyawan akan berkata: "untuk apa disiplin, sedangkan orang yang melanggar disiplin saja tidak pernah dikenakan sanksi". e. Ada tidaknya pengawasan pimpinan

Dalam setiap kegiatan yang dilakukan oleh perusahaan perlu ada pengawasan, yang akan mengarahkan para karyawan agar dapat melaksanakan pekerjaan dengan tepat dan sesuai dengan yang telah ditetapkan. Namun sudah menjadi tabiat manusia pula bahwa mereka selalu ingin bebas, tanpa terikat atau diikat oleh peraturan apa pun juga. Dengan adanya pengawasan seperti demikian, maka sedikit banyak para karyawan akan terbiasa melaksanakan disiplin kerja.

Orang yang paling tepat melaksanakan pengawasan adalah pimpinan organisasi. Pengawasan ini disebut juga dengan waskat atau pengawasan melekat. Pada tingkat mana pun ia berada, maka seorang pemimpin bertanggung jawab melaksanakan pengawasan melekat ini, sehingga tugas-tugas yang dibebankan kepada bawahan tidak menyimpang dari apa yang telah ditetapkan.

f. Ada tidaknya perhatian kepada para karyawan

Karyawan adalah manusia yang mempunyai perbedaan karakter antara satu dengan yang lain. Seorang karyawan tidak hanya puas dengan penerimaan kompensasi yang tinggi, pekerjaan yang menantang, tetapi juga mereka masih membutuhkan perhatian yang besar dari pimpinannya sendiri.

g. Diciptakan kebiasaan yang mendukung tegaknya disiplin. 
Kebiasaan positif itu antara lain: a) saling menghormati, b) melontarkan pujian sesuai dengan tempat dan waktunya, sehingga para karyawan akan turut merasa bangga dengan pujian tersebut, c) sering mengikutsertakan karyawan dalam pertemuanpertemuan.

Dengan kepemimpinan yang baik, seorang pemimpin dapat berbuat banyak untuk menciptakan iklim kerja yang memungkinkan penegakan disiplin sebagai proses yang wajar, karena para karyawan akan menerima serta mematuhi peraturan-peraturan dan kebijakan-kebijakan sebagai pelindung bagi keberhasilan pekerjaan dan kesejahteraan pribadi mereka. Black dalam mas'ud, 2000.

Menurut Hasibuan (Malayu S.P Hasibuan, 2005:194-198) pada dasarnya banyak indikator yang mempengaruhi tingkat kedisiplinan karyawan suatu organisasi, di antaranya :

1. Tujuan dan kemampuan

Tujuan dan kemampuan ini mempengaruhi tingkat kedisiplinan karyawan. Tujuan yang akan dicapai harus jelas dan ditetapkan secara ideal serta cukup menantang bagi kemampuan karyawan. Hal ini berarti bahwa pekerjaan yang dibebankan kepada karyawan harus sesuai dengan kemampuan karyawan bersangkutan agar karyawan tersebut bekerja dengan sungguh-sungguh dan disiplin dalam mengerjakannya.

Akan tetapi, jika pekerjaan itu diluar kemampuannya atau jauh di bawah kemampuannya maka kesungguhan dan kedisiplinan karyawan rendah. Disinilah letak pentingnya axas the right man in the right place and the right man in the right job.

2. Teladan pimpinan

Teladan pimpinan sangat berperan dalam menentukan kedisiplinan karyawan karena pimpinanan dijadikan teladan dan panutan oleh para bawahannya. Pimpinan harus memberi contoh yang baik, berdisiplin baik, jujur, adil, serta sesuai dengan perbuatan. Dengan teladan pimpinan yang baik, kedisiplinan bawahan akan ikut baik. Jika teladan pimpinan kurang baik (kurang berdisiplin), para bawahan pun akan kurang disiplin. Pimpinan jangan mengharapkan kedisiplinan bawahannya baik jika dia sendiri kurang disiplin. Pimpinan harus menyadari bahwa perilakunya akan dicontoh dan diteladani bawahannya. Hal inilah yang mengharuskan pimpinan mempunyai kedisiplinan yang baik agar para bawahan pun mempunyai disiplin yang baik pula.

3. Balas Jasa

Balas jasa atau gaji ikut mempengaruhi kedisiplinan karyawan, karena balas jasa akan memberikan kepuasan dan kecintaan karyawan terhadap perusahaan. Jika kecintaan karyawan semakin tinggi terhadap pekerjaan kedisiplinan akan semakin baik. Untuk mewujudkan kedisiplinan karyawan yang baik perusahaan harus memberikan balas jasa yang relatif besar. Kedisiplinan karyawan tidak mungkin baik apabila balas jasa yang mereka terima kurang memuaskan untuk memenuhi kebutuhan hidupnya beserta keluarga.

Jadi, balas jasa barperan penting untuk menciptakan kedisiplinan karyawan. Artinya semakin besar balas jasa semakin baik kedisiplinan karyawan. Sebaliknya, apabila balas jasa kecil kedisplinan karyawan menjadi rendah. Karyawan sulit untuk berdisiplin baik selama kebutuhan-kebutuhan primernya tidak terpenuhi dengan baik.

4. Keadilan 
Keadilan ikut mendorong terwujudnya kedisplinan karyawan, karena ego dan sifat manusia yang selalu merasa dirinya penting dan minta diperlakukan sama ddengan manusia lainnya. Keadilan yang dijadikan dasar kebijakan dalam pemberian balas jasa atau hukuman akan tercipta kedisiplinan yang baik. Manajer yang baik dalam memimpin selalu berusaha bersikap adil terhadap semua karyawan. Dengan keadilan yang baik akan menciptakan kedisiplinan yang baik pula.

5. Waskat (pengawasan melekat)

Waskat adalah tindakan nyata paling efektif dalam mewujudkan kedisiplinan karyawan perusahaan. Dengan waskat berarti atasan harus aktif dan langsung mengatasi perilaku, moral, sikap, gairah kerja dan prestasi kerja bawahannya.

6. Sanksi hukuman

Sanksi hukuman berperan penting dalam memelihara kedisiplinan karyawan. Dengan sanksi hukuman yang semakin berat, karyawan akan semakin takut melanggar peraturan-peraturan perusahaan. Berat atau ringan sanksi hukuman yang akan diterapkan ikut mempengaruhi baik buruknya kedisiplinan karyawan.

Sanksi hukuman harus dipertimbangkan secara logis, masuk akal dan diinformasikan secara jelas kepada karyawan. Pimpinan harus tegas dan berani bertindak untuk menghukum setiap karyawan yang indisipliner sesuai dengan sanksi hukuman yang telah ditetapkan. Sanksi hukuman ini terdiri atas hukuman disiplin ringan berupa teguran, hukuman disiplin sedang berupa penundaan gaji atau naik pangkat, dan hukuman disiplin berat berupa penurunan pangkat, pemberhentian dengan hormat sebagai pegawai atau pemberhentian secara tidak hormat sebagai pegawai.

\section{Ketegasan}

Ketegasan pimpinan dalam melakukan tindakan akan mempengaruhi kedisiplinan karyawan perusahaan, pimpinan harus berani dan tegas bertindak untuk memberikan sanksi sesuai dengan yang telah ditetapkan perusahaan sebelumnya. Dengan demikian pimpinan akan dapat memelihara kedisiplinan karyawan perusahaan.

8. Hubungan kemanusiaan

Hubungan kemanusiaan yang harmonis di antara sesama karyawan ikut menciptakan kedisiplinan yang baik pada suatu perusahaan. Manajer harus berusaha menciptakan suasana hubungan kemanusiaan yang serasi baik diantara semua karyawan. Kedisiplinan karyawan akan tercipta apabila hubungan kemanusiaan dalam organisasi tersebut baik.

Dari penjelasan di atas dapat diketahui bahwa banyak faktor yang dapat mempengaruhi disiplin kerja pegawai. Salah satu faktor tersebut adalah kompensasi atau gaji pegawai. Gaji yang rendah akan membuat pegawai tidak fokus dalam bekerja, sehingga mereka berusaha mencari penghasilan lain.

\section{Hubungan Disiplin Dengan Produktivitas Kerja}

Sumber daya manusia merupakan elemen yang paling strategis dalam organisasi, harus diakui dan diterima manajemen. Peningkatan produktivitas kerja hanya mungkin dilakukan oleh manusia. Oleh karena itu, memberikan perhatian kepada unsur manusia merupakan salah satu tuntutan dalam keseluruhan upaya peningkatan produktivitas kerja. 
Produktivitas kerja merupakan sikap mental. Sikap mental yang selalu mencari perbaikan terhadap apa yang telah ada. Suatu keyakinan bahwa seseorang dapat melakukan pekerjaan lebih baik hari ini daripada hari kemarin. (Malayu S.P Hasibuan, 2005:100)

Aigner mengatakan bahwa filsafat mengenai produktivitas sudah ada sejak awal peradaban manusia, karena makna produktivitas adalah keinginan dan upaya manusia untuk selalu meningkatkan kualitas kehidupan dan penghidupan di segala bidang. Dengan kata lain, filsafat produktivitas adalah keinginan manusia untuk membuat hari ini lebih baik dari hari kemarin dan membuat hari esok lebih baik dari hari ini. Sikap yang demikian akan mendorong seseorang untuk tidak cepat merasa puas, akan tetapi terus mengembangkan diri dan meningkatkan kemampuan kerja dengan cara selalu mencari perbaikan-perbaikan dan peningkatan.

Faktor utama yang mempengaruhi produktivitas kerja adalah kedisiplinan. Kedisiplinan pegawai memainkan peranan yang dominan, krusial, dan kritikal dalam keseluruhan upaya untuk meningkatkan produktivitas kerja para pegawai. Sebagaimana yang diketahui, disiplin kerja para pegawai sangat penting. Disiplin kerja merupakan hal yang harus ditanamkan dalam diri tiap karyawan, karena hal ini akan menyangkut tanggung jawab moral itu pada tugas dan kewajibannya. Seperti juga suatu tingkah laku yang bisa dibentuk melalui kebiasaan. Selain itu, disiplin dapat ditingkatkan apabila terdapat kondisi kerja yang dapat merangsang karyawan untuk berdisiplin.

Disiplin adalah sikap kesediaan dan kerelaan seseorang untuk mematuhi dan menaati segala norma peraturan yang berlaku dalam organisasi. Disiplin karyawan yang baik akan mempercepat pencapaian tujuan organisasi, sedangkan disiplin yang merosot akan menjadi penghalang dan memperlambat pencapaian tujuan organisasi. Peraturan disiplin dibuat untuk mengatur tata hubungan kerja yang berlaku tidak saja dalam organisasi-organisasi besar, tetapi juga pada sebuah organisasi yang memperkerjakan banyak sumber daya manusia untuk melaksanakan pekerjaan. Pembuatan suatu peraturan disiplin dimaksudkan agar para karyawan dapat melakukan pekerjaan tersebut sesuai dengan apa yang diharapkan. Oleh sebab itu, peraturan disiplin pada perusahaanperusahaan swasta tidak akan banyak berbeda dengan organisasi publik.

Disiplin merupakan faktor utama yang mempengaruhi produktivitas kerja. Moenir dalam Edy Sutrisno menyatakan bahwa disiplinisasi itu perlu untuk menciptakan lingkungan kerja yang tertib, berdaya guna, dan berhasil guna melalui suatu sistem pengaturan yang tepat. Sementara disiplin itu sendiri adalah ketaatan terhadap aturan. (Edy Sutrisno, 2016:96)

Disiplin kerja atau kebiasaan-kebiasaan baik yang harus ditanamkan dalam diri karyawan sebaiknya bukan atas dasar paksaan semata, tetapi harus lebih didasarkan atas kesadaran dari dalam diri karyawan.

Disiplin menunjukkan suatu kondisi atau sikap hormat yang ada pada diri karyawan terhadap peraturan dan ketetapan organisasi. Denfan demikian, bila peraturan atau ketetapan yang ada dalam organisasi itu diabaikan atau sering dilanggar, maka karyawan mempunyai disiplin kerja yang buruk. Sebaliknya, bila karyawan tunduk pada ketetapan organisasi, menggambarkan adanya kondisi disiplin yang baik. Dalam arti yang lebih 
sempit dan lebih banyak dipakai, disiplin berarti tindakan yang diambil untuk mengoreksi perilaku dan sikap yang salah pada sebagian karyawan.

Sasaran pokoknya adalah untuk mendorong disiplin diri karyawan untuk datang di kantor tepat waktu. Dengan datang ke kantor tepat waktu dan melaksanakan tugas sesuai dengan tanggung jawabnya, maka diharapkan produktivitas kerja akan meningkat.

Singkatnya, disiplin dibutuhkan untuk tujuan organisasi yang lebih jauh, guna menjaga efisiensi dengan mencegah dan mengoreksi tindakan-tindakan individu dalam I'tikad tidak baiknya terhadap kelompok. Disiplin yang baik mencerminkan besarnya tanggung jawab seseorang terhadap tugas-tugas yang diberikan kepadanya. Hal ini mendorong gairah kerja, semangat kerja, dan terwujudnya tujuan organisasi. Melalui disiplin akan mencerminkan kekuatan, karena seseorang yang berhasil dalam karyanya adalah mereka yang memiliki disiplin tinggi. Jadi, kedisiplinan merupakan kunci keberhasilan suatu organisasi dalam mencapai tujuan.

Dari penjelasan tersebut di atas dapat disimpulkan bahwa produktifitas kerja pegawai dalam suatu organisasi sangat dipengaruhi oleh disiplin pegawai. Apabila di antara pegawai sudah tidak menghiraukan kedisiplinan kerja, maka dapat dipastikan produktivitas kerja akan menurun. Padahal untuk mendapatkan produktivitas kerja sangat diperlukan kedisiplinan para pegawai.

\section{A. KESIMPULAN}

1. Disiplin adalah sikap mentaati peraturan dan ketentuan yang telah ditetapkan oleh organisasi baik yang tertulis maupun yang tidak tertulis dengan penuh kesadaran dan tidak mengelak dangan sanksi-sanksi apabila melanggar tugas dan wewenang yang diberikan kepadanya. Dengan kata lain, disiplin adalah sikap menaati peraturan dan ketentuan yang telah ditetapkan tanpa pamrih.

2. Pembinaan disiplin tidak akan dapat terlaksana, bila tidak ada aturan tertulis yang pasti untuk dapat dijadikan pegangan bersama. Disiplin tidak mungkin ditegakkan bila peraturan yang dibuat hanya berdasarkan instruksi lisan yang dapat berubah-ubah sesuai dengan kondisi dan situasi.

3. Adapun strategi manajemen disiplin adalah sebagai berikut: 1) Rumusan ketetapannya jelas, aturannya masuk akal, dipublikasikan, dan dijalankan secara hati-hati, 2) Pelaksanaannya adil dengan menggunakan peringatan dan hukum yang dimaklumkan, 3) Kepemimpinan penyeliaan yang disesuaikan pada aturan-aturan pendisiplinan, 4) Pelaksanaan yang adil dan seragam. 


\section{DAFTAR PUSTAKA}

Arifin dan Barnawi, Etika Profesi Kependidikan, Jogjakarta:Ar-Ruzz Media, 2012

Davis, Keith dan John W. Newstrom, Perilaku Dalam Organisasi, Jakarta: Erlangga, T.th

Hasibuan, Malayu S.P, Manajemen Dasar, Pengertian Dan Masalah, Jakarta: PT Gunung Agung, 1996

Mangkunegara, Anwar Prabu, Perencanaan Dan Pengembangan Sumber Daya Manusia, Bandung: Rafika Aditama, 2003

Mulyasa, E., kurikulum berbasis sekolah, Bandung: Remaja Rosdakarya, 2002

Rasdiyanah, Andi, Pendidikan Agama Islam, Bandung: Lubuh Agung, 1995.

Simamora, Henry, Manajemen Sumber Daya Manusia, Yogyakarta: STIE YKPN, 1997.

Singodimedjo, Markum, Manajemen Sumber Daya Manusia, Surabaya: SMMAS, 2000.

Sutrisno, Edy, Manajemen Sumber Daya Manusia, Jakarta: Prenadamedia Group, 2016.

Siagian, Sondang P., Manajemen Sumber Daya Manusia, Jakarta: PT Bumi Aksara, 2008.

Salam, Abdus, Manajemen Insani dalam Bisnis, Yogyakarta: Pustaka Pelajar, 2014.

Tohardi, Ahmad, Pemahaman Praktis Manajemen Sumber Daya Manusia, Bandung: Universitas Tanjung Pura. 